\title{
Collective Action, Innovation, and Wealth Generation Among Settled Pastoral Women in Northern Kenya
}

\author{
D. Layne Coppock ${ }^{1}$ and Solomon Desta ${ }^{2}$
}

Authors are ${ }^{1}$ Associate Professor, Dept of Environment and Society, Utah State University, Logan, UT 84322, USA; and ${ }^{2}$ Consultant, MARIL PLC, Addis Ababa, Ethiopia.

\begin{abstract}
Collective action occurs when people join together to tackle problems of common interest. Collective action can be an effective means of group problem solving, especially among poorer residents of densely populated urban areas or farming systems. Few examples have been documented, however, for the lightly populated rangelands, where pastoralists are better known for their social independence and opportunistic behavior. We were therefore surprised to encounter dynamic women's collective-action groups in small settlements throughout north-central Kenya, a pastoral region characterized by high rates of poverty, few public services, recurrent drought, and ethnic conflict. We wanted to understand why groups were created and how they functioned. We used a semistructured questionnaire to interview representatives from 16 groups in February 2006. Results indicated that most groups had formed since the 1990s. They emerged either spontaneously or after encouragement from local developmentagency staff. Founding members were exclusively women who were often illiterate and poor. Groups have elected leaders and are governed under constitutional frameworks with extensive bylaws. Groups form to improve living standards for members, and numerous success stories were noted. Groups undertake activities including microfinance, livelihood diversification, and mitigation of drought effects; they also spearhead and fund community education and health initiatives. A tally of 63 groups created over the previous $25 \mathrm{yr}$ indicated that 2 had collapsed, 47 were thriving, and 14 were failing. Group failure was most attributed to poor leadership and negative interpersonal dynamics among members, but important external threats included drought, poverty, political incitement, illiteracy, and agitation by men. In a region beset by large challenges it is notable that such grassroots innovation can help fortify social, human, and financial capital and this, in turn, can improve risk management and human well-being. Collective action should be recognized as a vital development process in Kenya's rangelands that deserves more policy-level attention.
\end{abstract}

Key Words: drought management, Greater Horn of Africa, human organization, poverty reduction, risk management, rural development

\section{INTRODUCTION}

Collective action is defined by Meinzen-Dick and DiGregorio (2004) as "a voluntary action taken by a group to achieve common interests." Collective action is increasingly recognized as a positive force for improving lives in the developing world, especially among the poor (Grootaert 2001). There are many forms of collective action, and objectives vary from increasing incomes and well-being of members to influencing policies, developing human and social capital, and fostering social networking. Both men and women can engage in collective action, either in gender-restricted or mixed groups (Mayoux and Hartl 2009). Benefits and costs of cooperation change over

This publication was made possible through support provided to the Pastoral Risk Management (PARIMA) project under the auspices of the Global Livestock Collaborative Research Support Program (GL-CRSP) by the Office of Agriculture, Bureau of Economic Growth, Agriculture and Trade, US Agency for International Development (USAID) under the terms of Grant No. PCE-G-00-98-00036-00 to the University of California, Davis. The opinions expressed herein are those of the authors and do not necessarily reflect the views of USAID.

At the time of research Desta was a research associate, Dept of Environment and Society, Utah State University, Logan, UT 84322, USA.

Correspondence: D. Layne Coppock, Dept of Environment and Society, Utah State University, Logan, UT 84322, USA. Email: Layne.Coppock@usu.edu

Manuscript received 17 November 2011; manuscript accepted 29 July 2012.

(c) 2013 The Society for Range Management time. Collective action can help fulfill short- or long-term needs for individuals and communities and is not an end in itself (Forsyth 2006).

For sub-Saharan Africa, Kenya is noteworthy in terms of having a long history of formal cooperative movements in higher-potential farming systems (Heyer 1976). Work by Place et al. (2004) describes more recent and less formal group initiatives that have emerged in Kenya's highlands. Such groups-often numerically dominated by women - undertake many activities, including income generation, asset building, marketing of farm commodities, and social functions. Although formal collective-action initiatives have been commonly observed in farming or urban areas, there is much less evidence of the same in the rangelands. Scant attention, for example, is given to collective behavior at a recent international rangelands conference (International Rangelands Congress [IRC] 2011).

Historically, the African rangelands have been occupied by pastoralists who manage widely roaming livestock that provide sustenance in the form of milk, meat, fiber, and herd accumulation (Holechek et al. 2010). Pastoral regions have been characterized by expansive landscapes and low densities of nomadic or seminomadic peoples that are members of loosely structured social networks. Such forms of social organization accommodate greater independence and opportunistic behavior among individuals and households, facilitating use of patchy, variable foraging environments. Some 
pastoral societies have traditionally relied on informal means of community-level cooperation for herding, lifting well water, and selling dairy products, but this is relatively limited in scope (Coppock 1994).

In recent decades there has been a trend toward sedentarization and settlement by East African pastoralists. This has resulted from the interaction of many social and ecological factors. Often, the people who settle have been ejected from the traditional pastoral system because they lost their livestock due to drought, disease, or theft. They initially settle to gain access to food relief and other public services (Fratkin 1997; Smith 1998; Fratkin and Roth 2005). An important underlying factor in the sedentarization process is human population growth. As numbers of people increase there is a decline in per capita livestock holdings because livestock are more directly affected than people by periodic limitations of forage and water due to drought and heavy stocking rates. Herd crashes result from animal starvation, and the ratio of milking stock to people suddenly drops (Desta and Coppock 2002). This downward spiral escalates the livelihood risks in particular for pastoralists who have only a few animals to start with, and many who exit the traditional system are unable to return (Desta and Coppock 2004). This is yet one more story in the saga that the rangelands of the developing world have become home to many destitute and marginalized people (Seré et al. 2008).

Although scholars often focus on the negative implications of sedentarization for maintaining rangeland livestock production systems and pastoral cultures, aggregation of the poor near towns and villages can give opportunity for income generation, collective action, and other forms of human capacity building. Settled pastoral women, in particular, can benefit from local opportunities to sell dairy products and firewood to town dwellers (Holden and Coppock 1992; Nduma et al. 2001). Ultimately, helping a surplus of displaced people find alternative or diversified livelihoods could benefit the ecological sustainability of pastoral systems by reducing local pressures on natural resources (Coppock 1994).

While undertaking a routine field trip in the remote rangelands of Isiolo District, north-central Kenya, we met women in a small settlement who told us stories of how they had transformed their community by creating an informal group that engaged in self-help activities. Starting with a savings and credit club, their efforts evolved into livelihood diversification schemes and eventually gave them the means to help support local public services including primary schools, health clinics, and natural resource management. Some women who had been impoverished sellers of firewood and charcoal reportedly became entrepreneurs in just a few years. Given that success stories here are rare, we were intrigued. We decided to visit a variety of settlements in the region with several objectives in mind. We wanted to find out how pervasive collective action was and verify the achievements we were hearing about. We also wanted to know why such groups were formed and how they functioned. Are they effective in reducing poverty and mitigating drought? Are they sustainable-and if so-what factors most contribute to sustainability? If collective action could be confirmed as a viable pathway out of poverty here, it would be notable in a region where the problems are large and solutions elusive (Arid Lands Resource Management Project [ALRMP] 2011).

\section{METHODS}

The study was conducted in what is now Marsabit District. The region has an arid, warm climate and is sparsely populated. Landscapes are dominated by sedimentary plains and volcanic formations. Vegetation consists of annual and perennial grasslands, shrublands, and bushlands. Livelihoods include pastoralism and agropastoralism in more remote locations, as well as smallholder farming and petty trade in and near small towns at higher elevations. Residents represent a wide variety of ethnic affiliations from the lowlands and highlands of eastern Africa. Physical infrastructure and public services are very marginal. Poverty is endemic and illiteracy rates are high. Other background information may be found in ALRMP (2011).

We were unable to construct a sampling frame of all possible collective-action groups in the study area; therefore, random sampling was not employed. Rather, our work focused on 16 women's groups in 16 settlements feasible for us to visit. All groups we encountered agreed to participate in the study and gave their informed consent.

A large (i.e., 70-question), semistructured survey was verbally administered to volunteer participants who came together and represented each group. The number of interviewees averaged four (range: one-eight) and included group leaders (chairladies), other group officers, and regular members. Answers to questions were based on consensus among interviewees. Interviews were conducted in Kiswahili and notes were taken on survey forms.

Surveys obtained information on 1) household attributes of group members; 2) details of group formation, structure, objectives, and function; 3) sources of external support; 4) group leadership and capacity building; 5) rights and responsibilities of members; 6) issues that affect group sustainability; 7) effects of group participation on personal economic status and quality of life; and 8) opinions on the dynamics and relative success of other groups in the vicinity. Respondents were asked to list important income sources and assets, at both group and individual levels. Some questions were open ended and elicited monologues, discussions, or other qualitative responses. Some questions involved use of rankings; for example, all group members were tallied in each interview and ranked by the interviewees according to educational skill level, wealth, and quality of life both prior to joining the group and at the present time. A 5-point scale was used for wealth status and quality of life (i.e., $1=$ very poor or very low, respectively; $2=$ poor or low; $3=$ intermediate; $4=$ wealthy or high; $5=$ very wealthy or very high). To illustrate wealth strata, the poor included people who largely survived by selling firewood or charcoal, and they often had few or no livestock assets. Members of the intermediate class could typically have up to a dozen head of livestock. Members of the wealthier class could have access to dozens of livestock, farm plots, and other opportunities for petty trade. A 7-point scale for literacy skills and exposure to formal education (i.e., $0=$ illiterate; $1=$ limited reading only; $2=$ limited reading and writing; $3=$ limited reading, writing, and arithmetic; $4=$ exposure to primary school; $5=$ exposure to secondary school; $6=$ exposure to college). Each group interview took several hours. Afterwards 
group financial and administrative records and physical assets were inspected to help confirm details given in the interview.

The overall survey period lasted $3 \mathrm{wk}$. Settlements were accessed near the main dirt tracks between Isiolo and Moyale towns. Research occurred during February 2006, which was a time preceded by a few years of near normal annual rainfall. There had been no recent droughts, spikes in ethnic conflict, or unusual political strife that might have biased the responses. Multiyear droughts had previously occurred in the early 1990 s and during 1999-2000, and these were used as benchmarks when assessing group progress in drought management. Data analysis was limited to descriptive methods.

Although the women we interviewed represented dominant pastoral ethnic groups in the region, they had sedentary lifestyles. They were linked to a wide variety of crop and livestock production systems. One women's group was in a mesic farming locale, and three others were in arid areas devoted to extensive livestock production. Eleven groups occurred in mixed, agropastoral locations.

\section{RESULTS}

\section{Group Formation and Growth}

On average, the 16 groups reportedly existed for $10 \mathrm{yr}$ (range: 2-19 yr) at the time of interview. The mean number of founding members-all women-was 17 (range: 7-28). Founders varied in ethnic affiliation and included Boran $(51 \%$ of founders), Rendille (28\%), Gabra (13\%), Sakuye (4\%), and others $(4 \%)$. Groups tended to be homogenous in ethnic affiliation, with nine being Boran, two Rendille, one Gabra, and one Sakuye. Three had mixes of Boran and Gabra. All but 4 of the 272 founders (i.e., $17 \times 16$ ) were married at the time of group creation. Fifty-eight percent of founders were reportedly illiterate when groups were created, with $15 \%$ exposed to formal education. Although 11 groups were primarily founded by women with some formal education, 5 were founded by women who were classified as illiterate. Most founding members were poor when the groups were created. The selfdeclared wealth distribution for founding members was $58 \%$, $37 \%$, and $5 \%$ from poorer, intermediate, and wealthier classes, respectively.

Eight groups showed little or no net change in membership between the time of establishment and time of interview. The others grew at highly variable rates, with one Rendille group increasing nearly 11 -fold (from 9 to 105 members) over $11 \mathrm{yr}$. The mean net change in group membership was 10 , as the average group size at the time of interview was 27 (range: $12-$ $105)$. When the largest group is excluded as an outlier, the mean net change was a net increase of five members, or $29 \%$.

The 432 group members at the time of interview (i.e., $27 \times 16)$ were reportedly all women and $97 \%$ were married. The mean age was $40 \mathrm{yr}$ (range: 17-75 yr). Twelve were single, widowed, or divorced. The women recruited after group establishment did not differ much from the founders in terms of education, wealth, or ethnic affiliation. Considering education, for example, $242(56 \%)$ of the 432 women were illiterate, consistent with the proportion of illiterate founders. Another $147(34 \%)$ had only a limited capacity to read, write, or do arithmetic. The remaining $43(10 \%)$ had been exposed to formal education as 33,5 , and 5 , respectively, had completed primary school, completed secondary school, or attended college. A couple of groups had $30-39 \%$ of their members exposed to formal education, but this was unusual. The other 14 groups had 0-4 members with formal education. Overall, the 432 group members reportedly came from households with seven other dependents on average. This suggests that around 3024 people (i.e., $432 \times 7$ ) were direct beneficiaries of the various collective action activities that were undertaken.

\section{Group Purpose and Governance}

Thirteen of 16 groups were formed to improve the economic circumstances of members, and the others formed because of evangelical motives. Groups reportedly were often created during droughts or other periods of socioeconomic stress. Eight groups formed after women had received encouragement from a governmental or nongovernmental organization (e.g., GO or NGO); in these instances guidance was provided on how to create and manage groups, and some material or financial support could be offered as an inducement. Such support varied from food-for-work to donation of a plot of land or providing key technology and training for endeavors such as honey production, milk processing, home construction, grain milling, bread making, or vegetable production. Initial grants or loans varied from Kenya shillings (KSh) 15 000-60 000 (US\$200-800). The eight other groups formed independently after observing the success of groups elsewhere. Older groups could assist newer groups by helping organize traditional, community-based fund-raising efforts (e.g., Harambee).

Group members could be recruited following open public meetings with minimal screening criteria. In other situations, however, founding members had well-defined goals-such as a desire to engage in dairy marketing, for example-or were bonded by a evangelical purpose. Most introductory meetings were facilitated by a GO or NGO. Every group we interviewed eventually formed long-term relationships with GO or NGO partners.

Most groups have gradually restricted recruitment of new members. Respondents noted practical limitations on group size. New applicants may be solicited by public notice or wordof-mouth communication. Applicants have been required to be female and must not be members of other groups. Applicants are carefully screened based on criteria that include trustworthiness and aptitude to be a team player. The ability to bring new skills to a group can be important. Applicants are interviewed and a vote of the membership is often taken for final approval. Admittance to a group may depend on the performance of the applicant during a probationary period. Entry fees are common and range from KSh500-6000 (US\$680) per person.

Although rare, there are formal procedures if a person wants to leave a group. Departure must be justified to the leadership. In other cases an unexplained departure for over a year can lead to dismissal of a group member. Women who petition to leave a group may have to relinquish their accumulated group benefits, but they are typically allowed to withdraw personal resources. In some cases a woman may receive a cash award upon departure if she has a positive record of group accomplish- 
ments. In general, groups want to encourage stability in membership. If a member dies, she can be replaced by another female from her family. If such a female is lacking, benefits or assets that the deceased had acquired can be passed to her family in general.

All groups are reportedly self-governed with reference to a constitution and bylaws. In most cases groups received valuable assistance from GO or NGO partners to help draft these documents. In other instances, however, new groups obtained information from existing groups or had to rely on talents of key members to prepare their own guidelines or models. Despite the high proportion of group members classified as illiterate, they take pride in having detailed, memorized knowledge of their constitutions and bylaws that outline leadership structures, rights and responsibilities of members, philosophy in serving the community, and administrative procedures. Constitutions may be amended. Group officers typically include a chairperson, secretary, treasurer, and a management committee.

Responsibilities of members focus on attending meetings, contributing labor for group activities, making monthly payments to group accounts, and actively supporting important functions. Less commonly mentioned responsibilities included assisting the poor or infirm and helping with group record keeping. Members must be informed voters with respect to the election of leaders and participation in group decision-making processes.

Privileges of members reportedly focus on participation in profit sharing and savings and credit (e.g., microfinance) activities. Members acquire loans at mutually agreed-upon repayment terms and can have access to funds to cover costs for child education, medicine, hospitalization, childbirth, funerals, weddings, and procuring livestock. Group membership allows for assistance with home construction and access to groupowned technology as well as employment at group-owned businesses. Group members have priority access to training and other capacity-building events, and can gain access to certain markets that group initiatives have penetrated.

In most cases group leaders are elected, but sometimes they are appointed. Candidates are screened based on their social reputation, character, and whether they possess development vision. The 16 groups documented 63 elections of chairpersons (e.g., chairladies); elections occur every 2-3 yr. Groups have had two chairladies on average (range: one to five). Secretaries and treasurers are appointed based on their literacy and numeracy skills, as they must record the minutes for meetings and track financial records. Leadership meetings are held weekly or monthly. Plenary membership meetings are held weekly, monthly, or annually. All but three groups reported that their leaders had received formal leadership training that was provided by GO and NGO partners.

All 16 groups were legally registered with the Kenyan government. Registration is beneficial because it improves group member's access to resources that include banking, work permits, and training opportunities. Linkages occur among women's groups at local or district levels. Groups may coordinate on fund-raising and multigroup development projects. Intergroup relations vary from cordial to competitive.

\section{Group Activities}

Groups planned to reduce poverty via microenterprise development and livelihood diversification. Group activities often initially focused on small-scale cultivation of grains and vegetables-produce that could be sold quickly and profitably. Profits were deposited in group savings accounts at local bank branches or invested in livestock production if environmental conditions were favorable. Once the savings grew to a sufficient size from profits, group membership dues, and accrued interest, microloans were then extended to help create microenterprises (i.e., milk processing, poultry production, grain milling, butcheries, tanneries, apiculture, bakeries, handicraft initiatives, etc.). Groups also reportedly raised money via Harambee events (e.g., community fund raisers where residents donate goats or sheep to be sold). Eventually, groups were able to support the emergency needs of HIV/AIDS orphans, the elderly, and infirm; they supported the construction of women's meeting halls, small hotels, and upgrades for school facilities. Meeting halls, in particular, were a crucial symbol of group identity and solidarity. Groups funded efforts to improve community hygiene via latrine construction and rehabilitation of water points; they paid primary school fees for the children of the neediest members and created scholarships for promising youths (boys and girls) to pursue secondary or tertiary education elsewhere. They gave special attention to enhancing community health via improvements in HIV/AIDS awareness education. Plans were underway to create a vocational training center.

Virtually all respondents recognized the vital role that livestock played in their local economies and the importance of livestock in the capital accumulation for women's groups. However, mere growth in the standing numbers of animals-a pastoral tradition-was rarely mentioned as an economic objective. Rather, livestock production was commercialized. Cattle fattening schemes, trading of cattle and small ruminants, sales of dairy products, as well as processing and sales of hides and skins, were repeatedly noted as value-adding activities. Animals and animal products were commonly sold to buy processed food and other items for consumption.

The role of external facilitating organizations changed as groups matured. In the early stages, GO and NGO partners tended to focus more on mentoring with respect to implementation of group constitutions and bylaws, along with providing start-up technical and financial assistance. In the latter stages, facilitation shifted more to leadership capacity building and improving the management of microfinance and microenterprises.

\section{Performance Indicators and Statistics}

According to the self-ranking exercises $(n=344$ in each case), group membership conferred gains in wealth status and quality of life, but had little effect on improving formal educational skills. Overall, on average, there was an improvement from level 2 to level 3 for both wealth and quality-of-life aspects, suggesting that most respondents perceived they had moved up from the poor to middle class. In contrast, little change was noted for education, with both means $<1$.

Important sources of group income and assets illustrated how diversified the groups had become when compared to the 




Figure 1. Estimates of aggregated (a) gross income sources and (b) asset sources for 16 women's groups in northern Kenya. Income is based on a grand total of KSh2 003000 (US\$26 707), whereas assets are based on a grand total of KSh9 130000 (US\$121733).

traditional pastoral focus on extensive livestock production (Figs. 1a and 1b). The average, declared current income per group was KSh125 175 (US\$1 669). The time frame recognized by interviewees varied, so the data only give a very rough indication of the relative importance among income sources. The largest income component was "other retail activity," and this included income from group-owned kiosks, veterinarysupply shops, bakeries, brick-making enterprises, and handicraft production (e.g., in one case a group sold beadwork internationally). "Livestock-related trade and retail" came in second and included commercial sales of fattened stock (especially cattle), proceeds from small-scale milk processing, as well as income from group-owned butcheries and tanneries. The third largest category was "fund raising, dues, and interest"; this included money obtained via Harambee events, membership dues, and interest on group bank accounts. The two smallest categories were "farm products and services" and "other rental services." The former was comprised of rentals of group-owned draught animals (i.e., donkeys, oxen, camels) for plowing or portage, fees from grain milling at group-owned facilities, and sales of grains, pulses, and vegetables. "Other rental services" included income derived from rental of groupowned and operated structures including personal dwellings (i.e., huts to multiroom houses), small hotels, meeting halls, retail shops, and, in one case-a tourist campground. In most cases the groups had commissioned the original construction of these facilities.
The average declared value of group assets was estimated as KSh570 600 (US\$7 608). Interviewees had less difficulty enumerating group assets; therefore these data may be viewed with more confidence than the income data. By far the largest category for group assets was land and structures (Fig. 1b). These were reported as group owned, but in some cases it is possible that land-in particular-may have been accessible based on long-term leases. Land primarily included tillable ground for the production of grains, grass hay, or vegetables, but it also involved plots associated with group-owned structures. Land value constituted about $17 \%$ of the total for the "land and structures" category. Structures were mostly built for group members to use for meetings, retail purposes, or as personal residences. Building materials included cement, locally made bricks, or sun-dried mud spread over wooden lattices. Roofing for larger structures consisted of tin sheeting covering a framework of wooden poles. Financial assets came in second place, and these included funds in group savings accounts as well as all outstanding loans. Capital equipment included physical items of relatively high value such as water tanks, grain milling equipment, milk-processing hardware, sewing machines, and solar panels. Group livestock were the draught animals. Privately held livestock, however, were far more numerous and constituted an important part of the personal assets of members. Accumulated furnishings and supplies were comprised of furniture (i.e., desks, chairs, beds, storage and shelving units), utensils, and materials used to generate valueadded products.

When respondents ranked the most important group activities overall, five stood out: 1) microfinance, 2) community fund raising (e.g., Harambee), 3) investment in human health, 4 ) investment in formal education, and 5) assisting the neediest members to build assets by restocking private flocks of goats and sheep. When respondents ranked the most important individual activities overall, two stood out: 1) owning a kiosk, and 2) livestock trading, which included sales of live animals, dairy products, and hides and skins.

There was reported evidence that group formation served as a magnet for attracting donor support (i.e., funding, procurement of key technologies, and training). The average value of donor input in terms of grants, loans, and technology was estimated at KSh506838 (US\$6758), a range of KSh50 000 to KSh2.1M. Overall, there were 895 instances of group members receiving specialized training, whether this involved smallbusiness management, leadership and group dynamics, or participation in local and regional tours to see how other people attempted to solve development problems.

We asked for stories to describe attributes of the top three individual performers for each group. Most of the top performers started as members from the poorest wealth class. A common strategy for success was when women diversified to combine commercial livestock activities with small-scale retail ventures. This can be illustrated, for example, by a woman who raised small ruminants for sale and also ran a kiosk or had an interest in a small hotel or butchery. In unusual cases, retail ventures could involve a woman having access to a vehicle she could rent, a means to show videos to the public for a fee, or marketing handicrafts. An oft-mentioned attribute of the most successful people is their ability to handle detail, including an aptitude to keep accurate records, possessing a savings ethic, 
and having good business sense. Women can also benefit from additional activities pursued in some cases by their spouses.

Finally, we sought to clarify whether total capital (cash) accumulation for the group accounts had shown a net increase, net decrease, or had remained constant over the previous $5 \mathrm{yr}$. This was one way to assess financial stability. Fourteen groups provided sufficient information and variation was evident. Nine groups reported an increase in capital accumulation in at least 4 of $5 \mathrm{yr}$, whereas one group reported an increase in only 2 of $5 \mathrm{yr}$.

\section{Challenges to the Sustainability of Groups}

Respondents were asked to recall how their groups coped with two droughts, one in the first half of the 1990s and another in 1999-2000. In terms of the first drought, only 8 of the 16 groups existed at the time and several of these were in an early stage of development. In most cases no formal collective actions were attempted to mitigate effects of the first drought. One group reportedly redistributed some lactating stock to the poorest households and another extended some low-interest loans with generous repayment schedules. In a third case there was resource sharing among members in terms of food and cash as well as collaboration to sell firewood and charcoal.

By 1999, 15 of the groups had reportedly been formed. Overall, 10 groups took formal action to mitigate drought effects. The five groups that appeared to do little or nothing were only $2 \mathrm{yr}$ old on average in 1999 . Collective action for the 10 groups varied from provision of water, food, and cash gifts for the neediest members to fodder collection and storage, goat restocking after the drought, and extending low-interest loans. In some cases school fees were covered for those who lost livestock. The five groups that provided loans and restocking services were 9 yr old on average by 1999 (range: 4-14 yr old).

We sought opinions as to whether group members coped better with the 1999-2000 drought compared to peers in their home areas who were not members of a group. Although two groups were equivocal on this point, the other 14 provided a unanimous assessment that group benefits gave them a decided advantage in coping with drought. Most implied that the social networks created by their groups provided them with added financial and emotional support during a drought crisis. Specific examples included collective action to sell dairy products and engage in other forms of petty trade to generate income. The importance of microfinance was reiterated. Some respondents mentioned that the benefits of group membership were most evident after the drought had ended, as members were better able to restock themselves with the use of savings or loans extended by groups.

Respondents exhibited a general agreement as to the determinants of group success in general. Group characteristics that promote sustainability include unity of purpose, transparency and accountability of leadership, and making good business decisions that lead to diversified microenterprises. Blends of incentives and discipline are used to instill an ethos of shared rights and responsibilities among group members. Participation in savings and credit activity is a valuable means to instill values consistent with successful collective action. The ability of a group to secure external support from GO and NGO partners was also important for sustainability.
Table 1. Major challenges encountered by 16 women's groups in northern Kenya and examples of coping responses.

\begin{tabular}{cc}
\hline \multicolumn{1}{c}{ Major challenges ${ }^{1}$} & Associated coping responses \\
\hline $\begin{array}{c}\text { External factors } \\
\text { Drought (38 points) }\end{array}$ & $\begin{array}{c}\text { Traditional and nontraditional coping tactics } \\
\text { (forage and water management, destocking, } \\
\text { livelihood diversification, soft loans to the } \\
\text { poorest members) }\end{array}$ \\
Poverty, resource scarcity & Loan disbursement, microenterprise development, \\
(29 points) & community fundraising (i.e., Harambee), \\
& securing external donor support \\
Poor markets, roads & Political advocacy activities \\
(27 points) & \\
Political incitement & Mediation activities, peace meetings, avoid \\
(21 points) & politics \\
Conflict/insecurity & Political advocacy activities, peace meetings \\
(16 points) & \\
Internal factors & \\
Unfavorable group & Conflict resolution and management, increased \\
dynamics ${ }^{2}$ (42 points) & frequency of meetings, changes in group \\
& leadership, re-education of members, securing \\
& external donor support, penalties for \\
Illiteracy (36 points) & misbehaving members \\
Agitation by men (16 & Adult literacy training \\
points) & Conflict resolution and management, gender \\
\hline
\end{tabular}

${ }^{1}$ Where respondents ranked factors from very high (5) to very low (1). Point tallies are added across groups. A maximum score would be $16 \times 5=80$. Only the most important factors are illustrated. Other minor challenges mentioned included (in reverse order of point totals): lack of rural banking options, competition among groups, inadequate community support, lack of skills among members, disease (for livestock and people), and scarcity of water.

${ }^{2}$ Includes passive members, internal strife among members, and poor leadership

We asked group representatives to rank up to five major problems that have threatened their survival and what they have done to deal with such challenges. Reported results are summarized in Table 1 . Both internal and external factors pose significant challenges to the well-being of the groups. The groups, however, are developing a diverse repertoire of coping responses that vary from the realm of natural resource management and group dynamics to adult education and political lobbying. In some cases agitation from men has been a problem, although most groups indicated that over the long term, men have gradually adjusted to the social changes that accompanied the emergence of women's groups. Thirteen groups indicated that men in their home areas have formed their own groups after the men had observed the success of women's groups. The respondents briefly discussed their impressions of the 13 men's groups. The men's groups had been formed after 1996. Of the 13 groups, 6 reportedly have had a satisfactory performance. Those that appear most successful have been focused on livestock trading, and this suggests that men's groups do not embrace the wide array of social and economic activities that the women's groups do. Of the other seven remaining men's groups, two have failed and the others are regarded as poor performers.

We asked group representatives to rank the most important interventions that have promoted their sustainability. Overall, 
the acquisition of major funds was most important, whether the funds came from Harambee, GOs, NGOs, or other donors. The second most important intervention involved specialty training in microenterprise development, home economics, and group leadership dynamics. Less mentioned was the donation of key technologies (i.e., draught oxen, grain milling equipment) and organizational or technical assistance that allowed penetration of new markets.

We asked respondents to list other women's groups that have formed in their respective areas. They reported 63 other groups in total that had been formed over the past $25 \mathrm{yr}$. The temporal distribution was that 4 groups formed in the 1980s, 24 formed in the 1990s, and 35 formed since 2000, clearly suggesting an upward trend. The respondents indicated that of these 63 groups, 61 still existed at the time of our survey. Of these 61, about 14 were regarded as failing while 47 were considered successful. Failure or near-failure of neighboring groups was largely attributed to negative internal dynamics such as poor leadership, uncooperative members lacking a shared vision, and mismanagement of group funds. One negative external factor of note was political incitement or interference that disrupted group activities. Illiteracy, drought, and lack of external support were only rarely mentioned as contributors to the failure of women's groups.

\section{Future Plans and Advice for Success}

Table 2 summarizes future plans for the 16 groups. Plans were diverse and ambitious, illustrating the interplay between the livestock and nonlivestock economy. Most aspirations were dominated by hopes to create more physical structures, be they improved houses for members, meeting halls, shops, schools, training centers, health centers, or water tanks. Entrepreneurial actions were prominent and included plans to purchase vehicles, draught oxen, electric generators, and a photocopy machine. There were several instances where groups sought to expand microfinance operations.

Overall, the advice these groups had for other women contemplating forming new groups focused on foundations of good governance. For example, the purpose of the group needs to be well understood by the members. Constitutions and bylaws need to be well known by the members and abided by. The leadership must be honest, transparent, accountable, and visionary. The membership needs to have unity of purpose and show mutual respect for each other. They must value collaboration and should strive to accommodate each other's needs. Less commonly mentioned was that groups should avoid politics and personal conflicts of interest.

\section{DISCUSSION}

Although our research approach limits inference beyond the 16 groups, we are confident that important facts and patterns were revealed. Our inspection of group records and assets following each interview supported the verbal information given. These inspections did not constitute an independent confirmation of interview findings, but they provided useful validation nonetheless. The findings were remarkably consistent across groups, especially considering the settlements were often separated by hundreds of kilometers of desolate country. The effort of
Table 2. Priority future plans for 16 women's groups in northern Kenya.

Group
no. Important future plans

1 Construct a water tank to sell water. Construct more houses for members. Purchase more draught oxen and provide more loans to members.

2 Construct a small shop to sell foodstuffs. Construct a dip for livestock. Build a curio (handicrafts) shop.

3 Build a high school. Add a training center to the lodge. Increase the seed money for loans to members. Construct more houses for members.

4 Construct a lodge and a restaurant. Improve housing for members. Increase group capital. Expand income-generating activities and livestock trade.

$5 \quad$ More restocking members with animals. Improve housing for members. Provide members with children's school fees. Construct a vocational training center. Purchase a vehicle to use as a taxi. Build a private nursery school.

6 Construct a dairy. Buy livestock from profits accrued by the dairy. Support individual members to start small businesses through small loans.

7 Raise more funds to give loans to group members. Build an office, a shop, and a meeting hall. Buy a tractor and a trailer to help collect firewood to reduce the work for women.

8 Construct an underground water tank. Build a grain mill. Buy a photocopy machine and a generator. Improve the housing for members. Establish a vocational training center for girls. Construct a water cistern. Assist with payments for school fees for children of the poor.

$9 \quad$ Purchase a grain mill. Expand livestock trade and other income-generating activities. Establish an orphanage for children of HIV/AIDS victims.

10 Construct a lodge and a hotel. Construct a water tank. Start a butchery business. Purchase camels and donkeys for transport and hauling goods. Buy a pair of draught oxen. Start more trading in hides and skins.

11 Construct a water tank. Construct a meeting hall. Establish a revolving fund to build more houses for members.

12 Construct a lodge. Construct a new water tank and rehabilitate the existing one. Venture more into livestock trade. Improve housing for members. Buy a vehicle to use as a taxi.

13 Organize a Harambee for construction of a shop. Build a nursery school. Increase the amount of our revolving fund.

14 Improve the marketing of beadwork. Explore other income-generating options. Build more houses for members.

15 Construct a lodge and a social hall. Restock members with animals. Improve housing for the members.

16 Buy a grain mill. Expand the livestock business. Construct a lodge. Restock members with animals. Improve housing for members. Purchase draught oxen for the group farm.

various $\mathrm{GO}$ and NGO partners to use collective action to stimulate social change and improve rural lives here have succeeded, a story that is rarely told. A common model for collective action has been adopted, offering opportunities for extension elsewhere (Coppock 2010; Coppock et al. 2011, 2012). That settled pastoral women seek opportunities to increase and diversify income by creating small, informal associations is known (Holden and Coppock 1992; Nduma et al. 2001), but what we have observed here takes cooperative behavior in pastoral areas to a much higher level. And despite 
popular images of pervasive destitution, illiteracy, and violence for this region, we were highly impressed with the optimism, innovativeness, and ambitions of the people we interviewed. They readily embraced democratic ideals in the governance system of collective action and were very articulate and passionate about their achievements.

Sedentarization has been implicated in many systemic ills for pastoral societies (Fratkin and Roth 2005). Settlement can concentrate inappropriately large numbers of people and livestock on fragile landscapes, resulting in localized overgrazing, excessive fuel-wood harvest, soil erosion, pollution, and higher livestock losses during drought. For human and animal health, poverty-ridden towns lacking clinics or veterinary services can be epicenters for disease transmission. Compared to mobile peers, settled pastoralists can have nutritionally inferior, carbohydrate-based diets that are low in animal source food content. In view of such dilemmas, agencies have long sought to engage refugees in restocking or small-scale farming programs so they may eventually re-enter the traditional pastoral sector; such efforts have had varied success (Unruh 2007). Not all aspects of sedentarization are negative, however. Settlement can improve the access of pastoralists to food, formal education, and physical security (Fratkin and Roth 2005).

Our research illustrates that sedentarization can have a pronounced silver lining for some pastoralists. Given opportunities for collective action and capacity building, settled pastoral women-in particular-can markedly elevate their well-being. This is despite the superficial impressions of outsiders that small, rangeland towns offer little, if any, margin for economic development. If such women were isolated and widely scattered in the back country, their ability to create similar degrees of life change would be practically nil.

It could also be assumed that contemporary, settled pastoralists could be less able to exploit their vast and highly variable rangeland environments efficiently, but this again underestimates their scope for pragmatic, cultural adaptation. Settled pastoralists have been observed to incorporate both sedentary and mobile elements in their livelihoods. For example, some members of a household can be town-based entrepreneurs, whereas others look after the family livestock holdings in distant locations (Fratkin and Roth 2005).

Collective action has improved several dimensions of risk management for group members and other direct beneficiaries in their communities. These dimensions include increased wealth, diversified livelihoods, and enhanced access to externally generated donor resources. A dynamic community planning ethos has also been spawned that increases the use of information. These attributes help communities buffer themselves against the frequent ecological or financial shocks that characterize northern Kenya. This is especially important because rural Kenyans have few government safety nets to rely on in times of crisis. This is very different from the western United States, where dozens of state and federal programs help protect ranchers during severe drought (Coppock 2011).

At the heart of livelihood change for the members of collective-action groups is the idea that complementary linkages between the livestock and nonlivestock economies can strengthen the whole. Few would dispute that livestock production is the critical comparative advantage in this region, but being cleverer in terms of destocking and restocking relative to ecological or financial dynamics makes sense. For example, respondents often noted the wisdom of anticipating drought, selling excess stock in advance when prices are higher, investing proceeds in small businesses or improvements in living standards, and then restocking via business profits when rainfall conditions improve. This illustrates creation of a virtuous cycle from the maw of a vicious cycle that unfortunately still characterizes many of today's more traditional "boom and bust" pastoral systems. In these latter cases, when a drought occurs large numbers of livestock suddenly die and millions of dollars in current assets and future milk production vanish. The net result is that most people become poorer, all for lack of diversified investment options and livestock markets that are unable to absorb large numbers of low-quality (e.g., malnourished or sickly) animals under crisis conditions (Desta and Coppock 2002, 2004).

In general, the utility of collective action here echoes that observed in other places where the poor have been compelled to organize themselves and create a critical mass to stimulate local development processes (Grootaert 2001; Meinzen-Dick and DiGregorio 2004; Place et al. 2004). Collective action may take different forms in different contexts; here it is a form of social cooperation that includes coordination of activities and information sharing linked by rules and responsibilities (Poteete and Ostrom 2004). This is unlike collective action where management of a commonly held natural resource is the central impetus. Study of collective action via multimethod approaches has been recently recognized as a means to illuminate pathways for poverty reduction (Mwangi and Markelova 2009).

Interviewees also gave testimonials to the value of grassroots microfinance in helping them better manage money, extend loans, and diversify livelihoods. Yunus (1999) was a pioneer in promoting microfinance based on social collateral among poor women in southern Asia. He noted the cascade of positive personal and community effects that can accrue from small-scale, financial empowerment. Although misuse of community funds per se was implicated in the struggles of some women's groups-and we did not assess rates of loan recovery-our overall impression was that microfinance seemed to be handled well here. More recently, our direct experience with 5360 microloans extended among Ethiopian pastoral women confirms very high rates $(96 \%)$ of loan repayment, based to a large extent on this Kenyan model (Coppock 2010; Coppock et al. 2011, 2012).

Despite widespread recognition that microfinance has become a major weapon against global poverty-as evidenced by Dr. Yunus and the Grameen Bank receiving the 2006 Nobel Peace Prize-microfinance has received relatively little research attention from development scholars. Microfinance has expanded over the past three decades to be much more than merely a novel mechanism to extend microloans to small groups of poor people; microfinance has subsequently informed wide-ranging discussion about savings behavior, gender, risk management, and best practices for economic development. Current debates include the need to clarify the effectiveness of various forms of microfinance delivery as well as how microfinance processes influence social and economic change (Armendáriz and Morduch 2010; Karlan and Zinman 2011). 
Microfinance can indeed have ground-breaking impacts, but it is not a silver bullet for every situation. Failures occur. And institutional challenges have changed in instances where microfinance has evolved from nonprofit, grassroots movements to becoming consolidated in the commercial banking sector, illustrated by the growth of the Grameen Bank in Bangladesh (Armendáriz and Morduch 2010).

It has long been proposed that pastoralists could benefit from microfinance-most notably to promote nonpastoral income and asset diversification, improve asset liquidity, and better conserve capital otherwise stored in the form of droughtvulnerable livestock (Coppock 1994; Desta and Coppock 2002). The challenge has been how to implement grassroots microfinance programs where the people are illiterate and widely dispersed, and where access to conventional banking services to help backstop the process is limited. Such obstacles can be overcome with the use of stepwise approaches among settled pastoralists, and at relatively low cost (Coppock et al. 2011).

The secure stewardship of microloans is a critical foundation of trusted, accountable, and visionary leadership. These leadership attributes were repeatedly mentioned as the key to group sustainability. This is not surprising, given that effective leadership is a universal linchpin for the success of a wide variety of human organizations (Forsyth 2006; Maxwell 2007).

Scoones (1998) was one of the first to advance a multifaceted framework based on various forms of capital for the analysis of sustainable livelihoods. He noted that sustainable livelihoods are resilient in the face of stressors and shocks, and deficiencies in any of five capital stocks could hinder resilience. His five forms of capital were financial, human, physical, social, and natural. Financial capital refers to monetary assets, and human capital refers to personal knowledge, skills, health, and labor capacity. Physical capital refers to things like infrastructure; social capital refers to the emergent properties of human networks; and natural capital refers to land, livestock, forage, etc. We contend that collective action in northern Kenya has contributed to strengthening all five capitals-directly or indirectly-to varied degrees. The base process of collective action directly created social capital, with the next outcome being direct enhancement of financial capital via microfinance and Harambee. The extent that collective action and enhanced access to funds then led to investments in improving human shelter, clinics, water access, and school facilities suggests a building up of physical capital. Improved health and education, in turn, feeds back into human capital. Natural capital was enhanced in situations where the groups procured farmland, draught animals, new seeds, fertilizers, small ruminants for restocking, and veterinary inputs.

Although the economic impact of building social capital via these groups was not quantified, we would speculate that it could be large. Narayan and Pritchett (1999), working in farming systems of rural Tanzania, found that investment in social capital (e.g., group memberships) had a five- to eight-fold greater effect on household income compared to investments in human capital (e.g., formal education). Given that the clear majority of the founding members of the groups were illiterate-and most remained so-our situation would generally confirm this perspective.
The collective-action model here purposefully excluded men from the start, and this is common, especially in microfinance endeavors (Mayoux and Hartl 2009). This initially led to domestic conflicts because husbands were suspicious of their wives' motives for joining groups. Once the financial and capacity-building objectives of collective action became apparent, however, most husbands gradually accepted the idea and have adjusted to the changes in gender roles that accompanied the process ( $\mathrm{S}$. Tezera, personal communication, September 2011). One change has been that some women became the major income earners-and hence money managers-of households. Another is that some men had to assume more child-care duties when their wives needed to attend various group functions. The Kenyan women actively worked to win over their husbands in the early stages of the transition, and this knowledge was passed to Ethiopian women during crossborder exchange tours when the latter subsequently commenced their collective-action efforts (Coppock 2010; Coppock et al. 2012).

Why have men been excluded from the groups? Other interviews with Kenyan women indicate that men are generally viewed as a risk that can undermine collective action efforts (C. Radel, personal communication, September 2011). Men can be less reliable in terms of paying back microloans, and men may seek compensation from group activities that is excessive in relation to their efforts. And men can exert power over women to secure group resources they may not be eligible to receive ( $S$. Tezera, personal communication, September 2011). There are some advantages to having men in collaborative efforts, however, especially in the realm of livestock trading. This has been observed in mixed-gender groups in southern Ethiopia, where men are superior negotiators with livestock buyers.

Some of the Kenyan women interviewees noted that menonly groups have formed after men observed the success of the women's groups. It was noted that 13 men's groups had formed since 1996. Of these, six were viewed as successful according to the interviewees, and these focused on livestock trading. Men's groups do not embrace the wide array of social and economic activities that women's groups do. As evident from future plans, there are instances where some women's groups want to include men. In southern Ethiopia, mixed-gender groups have been less common than women-only groups, but there have been examples where men have exhibited superior leadership and innovative behavior in collective action involving both men and women (S. Tezera, personal communication, September 2011).

Rural women are particularly marginalized in the developing world. Isangula (2012) noted the central role that microfinance and building entrepreneurial capacity can play in improving the lives of poor rural women. In his review he found evidence that improved financial circumstances for poor women can reduce the likelihood of intimate-partner violence, lower the risk of HIV/AIDS, enhance mental health, and improve the general physical well-being of women and their family members. This is another testimony to the benefits cascade of microfinance described by Yunus (1999). A similar pattern has been observed among settled pastoral households in the Liben region of southern Ethiopia. A project there helped engineer economic empowerment among women, and this resulted in associated gains for human health, livestock health, adoption of forage 
technologies, and improved connectivity with local extension services (Coppock et al. 2011). In most cases, simply having more disposable income and a heightened level of personal confidence were the keys for women's success.

Whether the vehicle of change is microfinance, collective action, or improved access to education, from a global perspective such findings from the rangelands would not surprise Blumberg (1995) in the least. She considers the gradual economic empowerment of women since the 1970s to be revolutionary, with positive implications for the improved wealth and well-being of families and nations worldwide. Blumberg expects such trends to expand in the future.

Collective action in northern Kenya offers an array of benefits to the participants, their direct dependents, and communities at large. Several policies in place have assisted this process, most notably those facilitating formal registration and legal recognition of groups. In recent years the Kenyan government has also increased public access to free primary education; this could increase numbers of literate youths to join collective action efforts. Other policy initiatives that make small grants and technology accessible in rural areas would be helpful, as well as expanded opportunities for nonformal education. Improved infrastructure, such as the effort to tarmac the Isiolo-Moyale road, offers a myriad of potential benefits including improved security and enhanced livestock trade. The latter could justify merging local groups into larger cooperative associations.

There are limits to what collective action can achieve, however. Besides the internal and external threats to sustainability enumerated by our interviewees, collective-action groups need to be responsive to changing economic and social opportunities. Collective action must nurture the talents of members and integrate them in ways that benefit the collective interest-managing a balance between individual and group incentives is the key; otherwise the top talent may abandon groups to pursue their personal aspirations. This illustrates that collective action is not an end point per se, but rather a dynamic means to an end that ultimately accommodates the goals and needs of individuals (Forsyth 2006).

Our observations suggest that growth in the membership of the collective-action groups we studied has been modest. Although it is best practice for collective action efforts to start small and grow slowly to promote sustainability (Coppock et al. 2012), patterns suggest that limits to growth may be imposed by the marginal economic opportunities in the region. We have no idea how many collective-action groups could be supported, or to what extent competition could regulate group proliferation.

\section{IMPLICATIONS}

We have observed that collective action, as well as associated activities such as microfinance and livelihood diversification, offer opportunities to create wealth, better manage risk, and enhance lives for pastoral women and their families living in settlements of northern Kenya. This is important because rangelands in this part of the world are challenged by drought, poverty, population growth, underinvestment, social conflict, sedentarization, and environmental degradation. Even partial solutions to such dilemmas have been elusive. The women we studied convincingly illustrate that there are effective-and largely endogenous-efforts that can substantially improve lives under daunting circumstances. Development agents can use some of the principles in this article to stimulate or facilitate positive change under similar circumstances. Approaches can be modified for local conditions with the use of thoughtful, participatory methods that involve communities in problem solving. Enhancing the well-being of pastoral people is a worthy, but often overlooked, goal for effective rangeland stewardship.

\section{ACKNOWLEDGMENTS}

The authors appreciate the assistance of Mr. Adan Wako and Mr. Ibrahim Aden for data collection and Mr. Chachu Tadecha for facilitating access to local communities. Mr. Seyoum Tezera and Dr. Getachew Gebru provided useful discussions on collective-action issues. The 16 women's groups are thanked for their participation in the research. Comments from anonymous peer reviewers helped us improve this article.

\section{LITERATURE CITED}

[AlRMP] Arid Lands Resource Management Project II. 2011. AlRMP Web site. Available at: http://www.aridland.go.ke/index.php. Accessed 13 September 2011.

ArmendÁriz, B., and J. Morduch. 2010. Rethinking banking. In: The economics of microfinance. 2nd ed. Cambridge, MA, USA: The MIT Press. p. 1-27.

BLUMBERG, R. L. 1995. Introduction: engendering wealth and well-being in an era of economic transformation. In: R. Blumberg, C. Rakowski, I. Tinker, and M. Monteón [EDS.]. Engendering wealth and well-being: empowerment for global change. Boulder, CO, USA: Westview Press. p. 1-14.

Cорроск, D. L. 1994. The Borana plateau of southern Ethiopia: synthesis of pastoral research, development, and change, 1980-91. Systems Study No. 5. Addis Ababa, Ethiopia: International Livestock Center for Africa. $374 \mathrm{p}$.

Coppock, D. L. 2010. Action research, knowledge \& impact: experiences of the Global Livestock CRSP PARIMA Project in the southern Ethiopian rangelands. Davis, CA, USA: Global Livestock Collaborative Research Support Program (GL-CRSP), University of California. 37 p. Available at: http://digitalcommons.usu.edu/ envs_facpub/214/. Accessed 15 June 2012.

Coppock, D. L. 2011. Ranching and multiyear droughts in Utah: production impacts, risk perceptions, and changes in preparedness. Rangeland Ecology \& Management 64:607-618.

Coppock, D. L., S. Desta, S. Tezera, and G. Gebru. 2011. Capacity building helps pastoral women transform impoverished communities in Ethiopia. Science 334:1394-1398.

Coppock, D. L., S. Tezera, S. Desta, And G. Gebru. 2012. Achieving development impact among pastoral and agro-pastoral people: lessons learned in southern Ethiopia, 2000-2009. Addis Ababa, Ethiopia: Ethiopian Society for Animal Production. 65 p. Available at: http://digitalcommons.usu.edu/envs_facpub/507/. Accessed 15 June 2012.

Desta, S., and D. L. Coppock. 2002. Cattle population dynamics in the southern Ethiopian rangelands, 1980-97. Journal of Range Management 55:439-451.

Desta, S., And D. L. Coppock. 2004. Pastoralism under pressure: tracking system change in southern Ethiopia. Human Ecology 32:465-486.

ForsYth, D. 2006. Group dynamics. 5th ed. Belmont, CA, USA: Wadsworth Publishing. $680 \mathrm{p}$.

Fratkin, E. 1997. Pastoralism: governance and development issues. Annual Review of Anthropology 26:235-261.

Fratkin, E., and E. Roth [eds.]. 2005. As nomads settle: social, health and economic consequences of pastoral sedentarization in Marsabit District, Kenya. New York, NY, USA: Kluwer Academic Publishers. 296 p. 
Grootaert, C. 2001. Does social capital help the poor? A synthesis of findings from the local-level institutions studies in Bolivia, Burkina Faso, and Indonesia. Washington, DC, USA: World Bank. World Bank Local-Level Institutions Working Paper No. 10. 28 p.

HEYER, J. 1976. Achievements, problems and prospects in the agricultural sector. In: J. Heyer, J. K. Maitha, and W. M. Senga [EDS.]. Agricultural development in Kenya, an economic assessment. Nairobi, Kenya: Oxford University Press. p. 132.

Holden, S. J., AND D. L. Coppock. 1992. Effects of distance to market, season and family wealth on pastoral dairy marketing in Ethiopia. Journal of Arid Environments 23:321-334.

Holechek, J., R. Pieper, and C. Herbel. 2010. Range management in developing countries. In: Range management principles and practices. 6th ed. Upper Saddle River, NJ, USA: Prentice Hall. p. 337-346.

ISANGULA, K. G. 2012. Improving women and family's health through integrated microfinance, health education and promotion in rural areas. Journal of Sustainable Development 5(5):76-89.

[IRC] International Rangelands Congress. 2011. Proceedings of the IX International Rangelands Congress: diverse rangelands for a sustainable society. S. Feldman, G. Oliva, and M. Sacido [EDS.]. Rosario, Argentina: IRC. 2011. 791 p.

KaRLAN, D., AND J. ZINMAN. 2011. Microcredit in theory and practice: using randomized credit scoring for impact evaluation. Science 332:1278-1284.

MaxweLL, J. 2007. The 21 irrefutable laws of leadership. 2nd ed. Nashville, TN, USA Thomas Nelson, Inc. 312 p.

Mayoux, L., AND M. HaRtL. 2009. Overview, gender and rural finance. In: Gender in agriculture sourcebook. Washington, DC, USA: World Bank. p. 85-95.

Meinzen-Dick, R., AND M. DiGregoRIo. 2004. Brief 1: collective action and property rights for sustainable development: overview. In: R. Meinzen-Dick and M. DiGergorio Collective action and property rights for sustainable development. Washington, DC, USA: International Food Policy Institute. 35 p.
Mwangi, E., and H. Markelova. 2009. Collective action and property rights for poverty reduction: a review of methods and approaches. Development Policy Review 27:307-331

Narayan, D., and L. Pritchett. 1999. Cents and sociability: household income and social capital in rural Tanzania. Economic Development and Cultural Change 47:871-897.

Nduma, I., P. Kristuanson, and J. McPeak. 2001. Diversity in income-generating activities for sedentarized pastoral women in northern Kenya. Human Organization 60:319-325.

Place, F., P. Kristuanson, A. Makauki, G. Kariuki, and J. Wanglla. 2004. Assessing the factors underlying differences in achievements of farmer groups: methodological issues and empirical findings from the highlands of central Kenya. Agricultural Systems 82:257-272.

Poteete, A., and E. Ostrom. 2004. In pursuit of comparable concepts and data about collective action. Agricultural Systems 82:215-232.

ScOoNES, I. 1998. Sustainable rural livelihoods: a framework for analysis. Brighton, UK: Institute for Development Studies, University of Sussex. IDS Working Paper 72. $22 \mathrm{p}$.

Seré, C., A. Ayantunde, A. Duncan, A. Freeman, M. Herrero, S. Tarawal, and I. Wright. 2008. Livestock production and poverty alleviation-challenges and opportunities in arid and semi-arid tropical rangeland-based systems. Proceedings of the XXI International Grasslands Congress and the VIII International Rangelands Congress: multifunctional grasslands in a changing world. Vol. 1. 29 June-5 July 2008; Hohhot, China. Guangzhou, China: Guangdong People's Publishing House. p. $19-27$.

SMITH, K. 1998. Sedentarization and market integration: new opportunities for Rendille and Ariaal women of northern Kenya. Human Organization 57:459-468.

UnRUH, J. D. 2007. Restocking pastoralists in the Horn of Africa. Disasters 17:305320.

Yunus, M. 1999. The Grameen bank. Scientific American 281:114-119. 